Jurnal Pemikiran \& Penelitian Psikologi

\title{
PSIKOLOGIA
}

p-ISSN: $185-0327$

e-ISSN: $2549-2136$

www.jurnal.usu.ac.id/psikologia

\section{PENGARUH PSYCHOLOGICAL WELL-BEING DAN JOB EMBEDDEDNESS TERHADAP TURNOVER INTENTIONS}

\section{THE EFFECT OF PSYCHOLOGICAL WELL-BEING AND JOB EMBEDDEDNESS TOWARD TURNOVER INTENTIONS}

Fahmi Ananda, Deasy Anggreini Pane

Psikologia: Jurnal Pemikiran \& Penelitian Psikologi

Tahun 2017, Vol. 12, No. 1, hal.1-20

Artikel ini dapat diakses dan diunduh pada:

www.jurnal.usu.ac.id/psikologia

Dipublikasikan oleh:

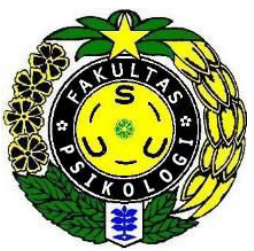

Fakultas Psikologi

Universitas Sumatera Utara

Jl. Dr. Mansyur No. 7 Medan. Telp/fax: 061-8220122

Email: psikologia@usu.ac.id 



\title{
PENGARUH PSYCHOLOGICAL WELL-BEING DAN JOB EMBEDDEDNESS TERHADAP TURNOVER INTENTIONS
}

\author{
Fahmi Ananda, Deasy Anggreini Pane
}

Universitas Sumatera Utara

\begin{abstract}
ABSTRAK
Penelitian ini bertujuan untuk mengetahui pengaruh psychological well-being dan job embeddedness terhadap turnover intention. Skala yang digunakan adalah skala turnover intention, skala psychological well-being dan skala job embeddedness. Subjek penelitian yang digunakan adalah 229 karyawan rumah sakit X. Data yang telah dikumpul diolah dengan menggunakan metode analisis berganda. Hasil analisis statistik menunjukkan bahwa psychological well-being dan job embeddedness berpengaruh negatif terhadap turnover intention. Dari hasil penelitian ini diharapkan pihak manajemen dapat mengelola psychological well-being dan job embeddedness sehingga dapat meminimalisir turnover intention.
\end{abstract}

Kata kunci : psychological well-being, job embeddedness, turnover intention

\section{THE EFFECT OF PSYCHOLOGICAL WELL-BEING AND JOB EMBEDDEDNESS TOWARD TURNOVER INTENTIONS}

\begin{abstract}
S
This research was aimed to examine the effect of psychological well-being and job embeddedness toward turnover intentions. This research used turnover intention scale, psychological well-being scale and job embeddedness scale. Data were gathered from 299 employees of X Hospital. Data were analyzed by using multiple regression method. The statistical analysis result showed there was a negative effect of psychological well-being and job embeddedness toward turnover intention. From the results of this research the hospital's management expected to manage psychological well-being and job embeddedness to reduced turnover intention.
\end{abstract}

Keywords : psychological well-being, job embeddedness, turnover intention

*Korespondensi mengenai penelitian ini dapat dilayangkan kepada: psikologia@usu..ac.id 
Isu penting dalam sebuah organisasi adalah memanfaatkan sumber daya manusia secara efektif untuk mencapai tujuan organisasi yang telah ditetapkan. Sumber daya manusia merupakan dasar dari setiap organisasi sehingga dibutuhkan pengelolaan sumber daya manusia yang mencakup penyediaan tenaga kerja yang bermutu, pengembangan kualitas sumber daya manusia dan pengendalian biaya ketenagakerjaan (Cascio, 1998). Pengelolaan sumber daya manusia dapat dilakukan dengan mempersipkan tenaga kerja yang terampil untuk meningkatkan produktivitas organisasi (Mufunda, 2006).

Piyachat dan Chanongkorn (2015) mengemukakan bahwa karyawan yang merasa kebijakan organisasi sesuai dengan kebutuhan mereka maka karyawan tersebut akan menunjukkan produktivitas yang lebih tinggi. Kinerja karyawan yang baik, tingkat stress kerja yang rendah dan keterlibatan karyawan yang tinggi pada pekerjaannya merupakan sikap kerja yang positif (Faslah, 2010).

Ketika seorang karyawan merasa apa yang mereka peroleh tidak sesuai dengan apa yang diharapkan di tempat kerjanya, maka turnover akan menjadi salah satu pilihan yang mungkin muncul (Faslah, 2010). Tingginya tingkat turnover pada organisasi akan memberikan banyak akibat seperti kondisi organisasi yang tidak stabil, peningkatan biaya rekrutmen dan pelatihan karyawan baru, turunnya integritas antar karyawan, serta penurunan efektivitas dan produktivitas organisasi (Mitchel, Holtom \& Lee, 2001).

Menurut Price (2001) turnover adalah pindahnya individu dari keanggotaan dalam suatu organisasi. Selanjutnya Price (2001) mengemukakan bahwa terdapat dua macam turnover yaitu voluntary turnover dan involuntary turnover. Voluntary turnover adalah keluarnya karyawan dari organisasi dengan kemauannya sendiri, sementara involuntary turnover adalah keluarnya karyawan berdasarkan keputusan perusahaan. Sementara dari sisi organisasi menurut Dalton, Tudor \& Krackhard (1987; Jewell \& Siegel, 1998) turnover dibagi menjadi dua macam yaitu turnover disfungsional dimana karyawan yang meninggalkan organisasi adalah karyawan yang ingin dipertahankan organisasi, dan turnover fungsional yaitu organisasi tidak keberatan dengan keluarnya karyawan. Turnover yang dimaksudkan pada penelitian ini adalah voluntary turnover.

Turnover yang dilakukan karyawan akan menyebabkan biaya secara langsung dan tidak langsung terhadap perusahaan. Biaya langsung yang akan dialami perusahaan adalah biaya rekrutmen dan seleksi serta biaya training karyawan baru (Staw, 1980). Sementara biaya tidak langsung yang dialami perusahaan adalah penurunan moral antar karyawan, kelebihan beban kerja dan hilang modal sosial karyawan (Dess \& Shaw, 2001).

$\mathrm{Y}$ yang merupakan perusahaan consulting multinasional melakukan survey pada organisasi di Indonesia pada tahun 2012 sehingga didapat data bahwa jumlah voluntary turnover di Indonesia mencapai $20,35 \%$ sementara jumlah voluntary turnover secara global hanya mencapai 8,24\% (Towers, 2012). Selanjutnya hasil survey Z, perusahaan konsultasi manajemen internasional pada tahun 2013 menunjukkan 
bahwa tingkat voluntary turnover di Indonesia mencapai 25,8\%, di mana Indonesia menjadi negara yang memiliki tingkat voluntary turnover tertinggi ketiga di dunia setelah India (26,9\%) dan Rusia (26,8\%) (Hay Group, 2013). Selanjutnya, hasil survey voluntary turnover yang dilakukan A, perusahaan consulting service di Amerika pada tahun 2014 terhadap 30.000 organisasi di dunia menunjukkan bahwa tingkat voluntary turnover keseluruhan industri sebesar 11\%, dimana voluntary turnover organisasi bidang hospitality sebesar 20,2\% diikuti organisasi bidang banking dan finance $13,3 \%$, bidang healthcare $13 \%$, bidang not-for-profit $11,2 \%$, bidang manufacturing, distribution dan service sebesar $8,6 \%$ dan bidang insurance sebesar $8,1 \%$ (www.compdatasurveys.com/benchmarkpro/ ) .

Munculnya sebuah perilaku didahului dengan adanya intention, intention adalah niat seseorang untuk melakukan suatu perilaku (Fishben \& Ajzen, 1975). Intention untuk melakukan turnover merupakan proses mengevaluasi hubungan kerja dengan perusahaan yang akan berhubungan dengan keputusan untuk melakukan tindakan turnover yang sesungguhnya atau tidak (Chiu \& Francesco, 2002). Turnover Intentions merupakan besarnya niat karyawan untuk keluar dari organisasinya (Griffeth, Hom \& Geatner, 2000). Turnover intention memberikan penjelasan terbaik untuk perilaku turnover karena intentions telah mencakup persepsi dan penilaian seseorang (Mobley, Griffith, Hand \& Meglino, 1979).
Berdasarkan hasil survey online yang dilakukan B, perusahaan human capital consulting terhadap 500 karyawan di Indonesia pada tahun 2015 diperoleh hasil $72 \%$ dari responden menyatakan bahwa dirinya berkeinginan untuk meninggalkan perusahaan tempatnya bekerja (turnover intention) dalam jangka waktu satu tahun mendatang (Michael Page, 2015).

Griffeth, Hom \& Geatner (2000) dalam penelitiannya mengemukakan bahwa turnover intentions adalah prediktor dalam menentukan perilaku turnover. Selanjutnya Lambert, Hogan \& Barton (2001) mengemukakan bahwa terdapat hubungan yang positif dan signifikan antara turnover intentions dengan perilaku turnover. Sejalan dengan hal ini, Radzi, Ramley, Salehuddin \& Jalis (2009) mengemukakan bahwa peningkatan turnover intentions pada karyawan akan menjadi indikator terbaik terjadinya turnover.

Harter, Schmidt \& Keyes (2002) dalam penelitiannya menyatakan bahwa psychological well-being karyawan berkaitan dengan turnover, produktivitas dan keuntungan perusahaan. Zahoor (2015) mengemukakan bahwa psychological wellbeing merupakan perasaan seseorang terhadap pengalaman dalam aktifitas seharihari, seseorang yang memiliki psychological well-being yang baik akan memiliki kondisi mental yang baik dan dapat menyesuaikan diri dengan lingkungan, sementara seseorang yang memiliki psychological well-being yang tidak baik akan memperlihatkan ketidakbahagiaan, hubungan sosial yang buruk, kesulitan untuk menyesuaikan diri dengan lingkungan dan performa yang buruk dalam pekerjaan. 
Stetz, Castro \& Bliese (2007) pada penelitiannya terhadap tentara di Amerika menunjukkan bahwa tentara yang memiliki psychological well-being yang rendah cenderung memiliki turnover intentions yang tinggi. Hal ini sejalan dengan hasil penelitian Amin dan Akbar (2013) yang mengemukakan bahwa pegawai hotel yang memiliki tingkat psychological well-being yang baik akan cenderung kurang memiliki niat untuk meninggalkan organisasi tempat mereka bekerja (turnover intentions).

Selanjutnya, Mitchell, Holtom \& Lee (2001) mengemukakan bahwa job embeddedness merupakan dorongan kognitif seseorang yang merupakan gabungan dari dimensi organisasi dan komunitas yang dapat menjaga seseorang untuk memilih bertahan pada pekerjaannya. Mitchell, Holtom \& Lee (2001) dalam penelitiannya membuktikan bahwa job embeddedness lebih mampu untuk memprediksikan voluntary turnover dibandingkan dengan faktor penentu yang selama ini digunakan untuk memprediksi voluntary turnover seperti kepuasan kerja, komitmen organisasi, mencari pekerjaan lain dan sikap kerja.

Mitchell, Holtom \& Lee (2001) mengemukakan bahwa faktor yang dapat menyebabkan individu memilih untuk melakukan turnover bukan hanya karena faktor organisasi dan individual tetapi terkadang disebabkan oleh suatu keadaan tiba-tiba yang dapat mempercepat individu untuk langsung memutuskan melakukan turnover. Beberapa individu dapat dengan mudah memilih untuk melakukan turnover tanpa berfikir matang sebelumnya, namun Mitchell, Holtom \& Lee (2001) mengemukakan apabila seorang individu terikat dengan organisasi, ketika muncul suatu keadaan walaupun individu tersebut memiliki pemikiran untuk melakukan turnover, individu tersebut akan berfikir ulang dikarenakan adanya keterikatan lain. Keterikatan ini yang disebut Mitchell, Holtom \& Lee (2001) sebagai job embeddedness yang merupakan keterkaitan, kecocokan dan keterikatan secara finansial seorang individu dengan keluarga, pekerjaan, komunitas serta lingkungan fisik dimana dirinya tinggal. Sehingga menurut Mitchell, Holtom \& Lee (2001) seorang individu yang memiliki job embeddedness yang tinggi akan tetap bertahan dalam organisasi walaupun berada pada lingkungan kerja yang tidak memuaskan.

Allen (2006) dalam penelitiannya mengemukakan bahwa job embeddedness berhubungan negatif dengan turnover intentions, job search behavior dan voluntary turnover. Hasil penelitian Halbesleben dan Wheeler (2008) yang mengemukakan bahwa karyawan yang memiliki job embeddedness yang tinggi yaitu karyawan merasa memiliki ikatan, kecocokan dan keterikatan secara finansial yang baik akan memilih untuk bertahan pada pekerjaannya. Hal ini sejalan dengan Takawira, Coetzee \& Schreuder (2014) yang dalam hasil penelitiannya menyatakan bahwa job embeddedness merupakan prediktor negatif yang kuat terhadap turnover intention, karyawan yang memiliki job embeddedness yang tinggi akan memilih untuk tetap bertahan pada pekerjaannya.

\section{Psychological Well-being dan Turnover Intentions}


Sumber daya manusia merupakan aset yang sangat penting untuk sebuah organisasi dikarenakan seberapa modern teknologi yang digunakan organisasi dan seberapa banyak dana yang dipersiapkan perusahaan tidak akan bermakna tanpa adanya sumber daya manusia yang profesional (Tjutju, 2008). Perkembangan ekonomi yang semakin pesat menuntut organisasi untuk melakukan perubahan-perubahan sehingga menyebabkan tekanan kepada karyawan. Tekanan yang dirasakan dapat menyebabkan karyawan merasa tidak cocok dengan tempat kerjanya, hal ini dapat berakhir dengan pilihan karyawan untuk keluar (turnover) dari pekerjaannya (Faslah, 2010).

Berdasarkan teori perilaku Fishbein dan Ajzen (1975) terdapat intention yang mendahului munculnya perilaku dan dapat memprediksikan munculnya perilaku tersebut, intention untuk turnover disebut dengan istilah turnover intentions. Turnover Intentions adalah besarnya niat karyawan untuk berhenti dari organisasinya (Griffeth, Hom \& Geatner, 2000).

Psychological Well-being merupakan hal penting bagi kesehatan karyawan dan keberhasilan jalannya organisasi (Macdonald, 2010). Selanjutnya, Macdonald (2010) mengemukakan bahwa meningkatkan psychological well-being karyawan akan memberikan manfaat untuk individu dan organisasi. Dalam dunia bisnis, investasi pada psychological well-being menjadi fokus dikarenakan investasi tersebut menunjukkan hasil yang baik untuk organisasi seperti meningkatnya performa karyawan dan menurunnya tingkat absensi karyawan. Absensi karyawan merupakan salah satu sikap negatif karyawan terhadap pekerjaannya dan dapat berakhir pada tindakan turnover (Gilmer, 1966).

Penelitian yang dilakukan Vandenberg dan Nelson (1999) menjelaskan bahwa komitmen organisasi, kepuasan kerja dan psychological well-being dapat menjadi prediktor dari munculnya turnover intentions. Selanjutnya dalam hasil peneltiannya Vandenberg dan Nelson (1999) mengemukakan bahwa bahwa karyawan yang telah memenuhi psychological wellbeing mereka akan lebih berkontribusi terhadap organisasi, lebih produktif dan akan memiliki turnover intentions yang rendah.

Hasil penelitian Beach, Brereton dan Cliff (2003) menjelaskan bahwa psychological well-being seseorang dapat mengurangi keinginan seseorang untuk meninggalkan pekerjaannya (turnover intention). Selanjutnya, hasil penelitian Harter, Schmidt dan Hayes (2002) mengemukakan bahwa tingkat psychological well-being yang baik pada karyawan dapat mengurangi tingkat turnover intentions pada karyawan.

Penelitian lain yang sejalan adalah hasil penelitian Harris \& Cameron (2005) mengemukakan bahwa psychological wellbeing yang dimiliki seorang individu dapat mengurangi turnover intention, meningkatkan peran individu dalam organisasi dan juga dapat mengurangi job dissatisfaction. Selanjutnya, Dike (2011) menunjukkan bahwa karyawan yang memiliki psychological well-being yang baik akan memilih untuk bertahan pada tempat kerjanya dan cenderung tidak akan melakukan turnover. 


\section{Job Embeddedness dan Turnover Intentions}

Tumbuhnya sebuah organisasi tidak terlepas dari adanya sumber daya manusia (SDM) berkualitas yang mendasari jalannya organisasi untuk mencapai tujuan. Organisasi memerlukan sumber daya manusia yang bermutu dan dapat mempertahankan kualitas kerja sehingga dapat mengendalikan biaya ketenagakerjaan (Cascio, 1998). Turnovernya karyawan dari pekerjaannya menunjukkan bahwa sebuah organisasi sedang mengalami masalah serius dikarenakan kehilangan karyawan yang berpotensi, menimbulkan biaya tambahan untuk rekrutmen dan training (Loi, Hangyue \& Foley, 2006). Mempertahankan karyawan merupakan hal yang menjadi perhatian khusus dalam suatu organisasi karena organisasi yang memiliki tingkat turnover yang tinggi dapat mengancam jalannya kinerja suatu organisasi (Singh \& Amish, 2015).

Untuk mempertahankan karyawan dalam suatu perusahaan diperlukan kombinasi dorongan kognitif yang didasari oleh faktor organisasi dan komunitas yang disebut dengan job embeddedness (Mitchell, Holtom \& Lee, 2001). Job Embeddedness mulai diakui sebagai faktor penting untuk mempertahankan karyawan dan dapat memberikan keuntungan kompetitif bagi organisasi (Bakker, Schaufeli, Leiter \& Taris, 2008).

Hasil penelitian (Mitchell, Holtom \& Lee, 2001) mengemukakan bahwan job embeddedness dapat mempertahankan karyawan untuk tetap bekerja pada organisasi dan dapat memprediksikan turnover intentions karyawan (Mitchell,
Holtom \& Lee, 2001). Selanjutnya, Fletcher (2005) yang menunjukkan bahwa job embeddedness memiliki hubungan negatif dengan turnover intentions. Selanjutnya, hasil penelitian Besich (2005) mengemukakan job embeddedness dapat memprediksikan turnover secara signifikan.

Sejalan dengan hasil penelitian tersebut, pada hasil penelitian Ramesh \& Gelfand (2010) menegaskan bahwa dikarenakan kemungkinan adanya resiko secara personal, maka karyawan yang merasa embedd dengan pekerjaannya akan cenderung lebih menunjukkan turnover intentions yang rendah. Selanjutnya, hasil penelitian Khattak, Hussain, Mehmood, Mumtaz, Rehman dan Rehman (2012) menunjukkan bahwa job embeddedness dapat mengurangi turnover dan dapat meningkatkan performa serta kepuasan kerja karyawan sehingga dapat mengurangi biaya tambahan perusahaan untuk seleksi, rekrutmen, pelatihan dan pengembangan karyawan.

Hasil penelitian lain yang sejalan adalah hasil penelitian Brian (2014) yang menunjukkan bahwa teori job embeddedness merupakan prediktor yang baik untuk memprediksikan turnover, sehingga karyawan yang memiliki job embeddedness yang baik akan memiliki turnover yang rendah dan sebaliknya.

\section{Pengaruh Psychological Well- being dan Job Embeddedness terhadap Turnover Intentions}

Pada era kompetitif ini turnover menjadi perhatian penting departemen sumber daya manusia di dalam suatu organisasi dan merupakan permasalahan serius yang 
dihadapi organisasi di seluruh dunia (Singh \& Amish, 2015). Turnover intention merupakan niat seorang karyawan untuk keluar dari organisasi tempatnya bekerja, turnover intention mendahului terjadinya turnover (Sharma \& Nambudiri, 2013). Dengan meningkatnya kompetisi dan tuntutan yang berasal dari lingkungan kerja maka penting untuk menanggapi turnover intention yang dimiliki karyawan (Singh \& Amish, 2015).

Individu yang memiliki psychological well-being yang baik akan memiliki produktifitas yang baik dan menunjukkan sikap positif terhadap pekerjaan, sehingga tingkat absensi dan tingkat turnover intentions akan menurun (Wright, 2009). Hal ini didukung dengan hasil penelitian Vaart, Linde, Beer \& Cockeran (2014) yang mengemukakan bahwa psychological wellbeing seorang individu dapat memprediksikan turnover intentions seseorang.

Bertahannya individu pada pekerjaan didasarkan pada proses kognitif karyawan dan faktor-faktor yang mempengaruhi, dorongan individu untuk bertahan pada organisasi merupakan job embeddedness (Mitchell, Holtom \& Lee, 2001). Individu yang memiliki job embeddedness yang tinggi akan memilih untuk tetap bertahan pada organisasi dan job embeddedness merupakan prediktor dari turnover intentions (Mitchel, Holtom \& Lee, 2001).

Hal di atas didukung oleh hasil penelitian Karatepe (2012) yang menunjukkan bahwa job embeddedness berhubungan negatif dengan turnover intentions sehingga karyawan yang memiliki job embeddedness yang baik akan menunjukkan tingkat turnover intentions yang rendah.

Berdasarkan uraian diatas, maka hipotesa yang diajukan adalah (1) Terdapat pengaruh negatif psychological well-being terhadap turnover intentions (H1). (2) Terdapat pengaruh negatif job embeddedness terhadap turnover intentions (H2). (3) Terdapat pengaruh psychological well-being dan job embeddedness terhadap turnover intentions.

\section{METODE}

\section{Subjek}

Dalam penelitian ini, sebanyak 229 kuesioner yang disebarkan kepada karyawan rumah sakit X. Setelah proses pengecekan kelengkapan pengisian kuesioner yang dilakukan oleh subjek, sebanyak 229 kuesioner layak untuk dianalisa lebih lanjut dengan tingkat pemberian respon sebesar $100 \%$.

\section{Metode Analisis Data}

Analisis statistik digunakan untuk menganalisis validitas dan reliabilitas alat ukur. Dalam studi ini, validitas alat ukur yang digunakan adalah validitas isi melalui kosultasi dengan dosen pembimbing (professional judgement) dan validitas konstruk melalui analisis faktor. Uji analisis faktor diawali dengan melihat Kaiser-MeyerOlkin (KMO) untuk mengukur apakah sampel yang digunakan dalam penelitian sudah cukup memadai. Wibisono (2013) menyatakan bahwa kriteria kesesuaian dalam penggunaan analisis faktor adalah nilai $\mathrm{KMO}>0$,5. Kemudian liat nilai Measures of 
Sampling Adequacy (MSA) dengan cara membandingkan besarnya koefisien korelasi yang diamati dengan koefisien korelasi parsialnya. Menurut Santoso (2002) angka MSA berkisar antara nol sampai dengan satu. Jika nilai MSA $=1$, maka variabel tersebut dapat diprediksi tanpa kesalahan oleh variabel yang lainnya. Apabila MSA $\geq$ 0,5, maka variabel tersebut masih dapat diprediksi dan dapat dianalisis lebih lanjut. Tetapi jika nilai MSA < 0,5, maka variabel tersebut tidak dapat dianalisis lebih lanjut atau dikeluarkan dari variabel lainnya. Selanjutnya, uji analisis faktor dapat dilihat dari nilai faktor loading yang menunjukkan besarnya korelasi antara variabel awal dengan faktor yang terbentuk. Santoso (2002) menyatakan bahwa validitas yang baik memiliki nilai faktor loading > 0,5. Untuk menguji hipotesis, penelitian ini menggunakan analisis multiple regression (regresi berganda).

\section{Instrumen Pengukuran Turnover Intentions}

Pengukuran turnover intentions

menggunakan kuesioner yang disusun berdasarkan perluasan aspek-aspek intention dari theory of planned behavior Ajzen (1991), yaitu attitude toward turnover, subjective norms towards turnover dan perceived behavioral control towards turnover. Kuesioner ini menggunakan model skala likert yang menggunakan lima pilihan jawaban, yaitu sangat sesuai (SS), sesuai (S), netral (N), tidak sesuai (TS) dan sangat tidak sesuai (STS). Skala disusun dalam dua jenis aitem, yaitu favorable (aitem yang isinya mendukung atau menggambarkan ciri atribut yang diukur) dan unfavorable (aitem yang isinya tidak mendukung atau tidak menggambarkan ciri atribut yang diukur). Hasil analisis faktor untuk dimensi attitude toward turnover diperoleh lima aitem dengan nilai KMO sebesar 0,820, nilai MSA bergerak dari 0,786 sampai dengan 0,886 dan nilai faktor loading bergerak dari 0,626 sampai dengan 0,870. Pada dimensi subjective norms toward turnover diperoleh lima aitem dengan nilai KMO sebesar 0,816, nilai MSA bergerak dari 0,776 sampai dengan 0,880 dan nilai faktor loading bergerak dari 0,738 sampai dengan 0,895. Selanjutnya, dimensi perceived behavior control toward turnover diperoleh lima aitem dengan nilai KMO sebesar 0,739, nilai MSA bergerak dari 0,618 sampai dengan 0,815 dengan nilai faktor loading bergerak dari 0,555 sampai dengan 0,782. Kuesioner ini terdiri dari 15 aitem dengan koefisien Alpha sebesar 0,936.

\section{Instrumen Pengukuran Psychological Well-being}

Pengukuran psychological well-being menggunakan kuesioner yang disusun berdasarkan dimensi-dimensi psychological well being oleh Ryff (1989), yaitu self acceptance, positive relations with other, autonomy, environmental mastery, purpose in life dan personal growth. Kuesioner ini menggunakan model skala likert yang menggunakan lima pilihan jawaban, yaitu sangat sesuai (SS), sesuai $(\mathrm{S})$, netral $(\mathrm{N})$, tidak sesuai (TS) dan sangat tidak sesuai (STS). Skala disusun dalam dua jenis aitem, yaitu favorable (aitem yang isinya mendukung atau menggambarkan ciri atribut 
yang diukur) dan unfavorable (aitem yang isinya tidak mendukung atau tidak menggambarkan ciri atribut yang diukur). Hasil analisis faktor untuk dimensi self acceptance, diperoleh lima aitem dengan nilai KMO sebesar 0,727 , nilai MSA bergerak dari 0,685 sampai dengan 0,800 dan nilai faktor loading bergerak dari 0,676 sampai dengan 0,753. Pada dimensi positive relations with others, diperoleh lima aitem dengan nilai KMO sebesar 0,736, nilai MSA bergerak dari 0,716 sampai dengan 0,773 dan nilai faktor loading bergerak dari 0,704 sampai dengan 0,773. Dimensi autonomy, diperoleh lima aitem dengan nilai KMO sebesar 0,709, nilai MSA bergerak dari 0,644 sampai dengan 0,779 dan nilai faktor loading bergerak dari 0,599 sampai dengan 0,890. Dimensi environmental mastery, diperoleh lima aitem dengan nilai KMO sebesar 0,817, nilai MSA bergerak dari 0,804 sampai dengan 0,839 dan nilai faktor loading bergerak dari 0,626 sampai dengan 0,776. Dimensi purpose in life, diperoleh lima aitem dengan nilai KMO sebesar 0,887, nilai MSA bergerak dari 0,853 sampai dengan 0,925 dan nilai faktor loading bergerak dari 0,839 sampai dengan 0,904. Sementara dimensi personal growth, diperoleh nilai lima aitem dengan nilai KMO sebesar 0,806, nilai MSA bergerak dari 0,754 sampai dengan 0,889 dan nilai faktor loading bergerak dari 0,536 sampai dengan 0,884 . Kuesioner ini terdiri dari 30 aitem dengan koefisien Alpha sebesar 0,966.

\section{Instrumen Pengukuran Job Embeddedness}

Pengukuran job embeddedness menggukan kuesioner yang disusun berdasarkan dimensi-dimensi yang dikemukakan oleh Mitchell, Holtom \& Lee (2001), yang terbagi dua yaitu on-the-job embeddedness dan off-the-job embeddedness. On-the-job embeddedness dibagi menjadi tiga dimensi yaitu linksorganization, fit-organization dan sacrificeorganization. Kemudian off-the-job embeddedness dibagi menjadi tiga dimensi yaitu links-community, fit-community, dan sacrifice-community. Skala ini menggunakan model skala likert yang menggunakan lima pilihan jawaban, yaitu sangat sesuai (SS), sesuai (S), netral (N), tidak sesuai (TS) dan sangat tidak sesuai (STS). Skala disusun dalam dua jenis aitem, yaitu favorable (aitem yang isinya mendukung atau menggambarkan ciri atribut yang diukur) dan unfavorable (aitem yang isinya tidak mendukung atau tidak menggambarkan ciri atribut yang diukur). Hasil analisis faktor untuk dimensi links-organization, diperoleh lima aitem dengan nilai KMO sebesar 0,792, nilai MSA bergerak dari 0,718 sampai dengan 0,891 dan nilai faktor loading bergerak dari 0,672 sampai dengan 0,908. Pada dimensi links-community, diperoleh empat aitem dengan nilai KMO sebesar 0,687, nilai MSA bergerak dari 0,657 sampai dengan 0,727 dan nilai faktor loading bergerak dari 0,578 sampai dengan 0,819. Dimensi fit-organization, diperoleh lima aitem dengan nilai KMO sebesar 0,726, nilai MSA bergerak dari 0,678 sampai dengan 0,808 dan nilai faktor loading bergerak dari 0,623 sampai dengan 0,860. Dimensi fitcommunity, diperoleh tiga aitem dengan nilai KMO sebesar 0,584, nilai MSA bergerak dari 0,561 sampai dengan 0,632 dan nilai faktor loading bergerak dari 0,633 sampai dengan 0,783. Dimensi sacrificeorganization, diperoleh empat aitem dengan 
nilai KMO sebesar 0,641, nilai MSA bergerak dari 0,620 sampai dengan 0,684 dan nilai faktor loading bergerak dari 0,617 sampai dengan 0,748. Sementara dimensi sacrifice-community, diperoleh empat aitem dengan nilai KMO sebesar 0,607, nilai MSA bergerak dari 0,574 sampai dengan 0,706 dan nilai faktor loading bergerak dari 0,599 sampai dengan 0,892. Kuesioner ini terdiri dari 25 aitem dengan koefisien Alpha sebesar 0,946 .

\section{HASIL}

\section{Karakteristik}

Deskripsi mengenai karakteritik subjek menunjukkan bahwa sebagian besar subjek adalah wanita dengan jumlah 139 orang $(60,69 \%)$. Mayoritas usia subjek pada tingkatan 20 sampai 40 tahun dengan jumlah 152 orang $(66,4 \%)$. Sedangkan berdasarkan tingkat pendidikan sebagian besar subjek memiliki tingkat pendidikan D3 sebanyak 110 orang $(48,03 \%)$. Lebih lanjut dapat dilihat pada Tabel 1.

\section{Hasil Analisis Statistik}

Berdasarkan analisis partial correlation menunjukkan bahwa psychological wellbeing dan job embeddedness berkorelasi negatif terhadap turnover intentions. Kemudian, analisis partial correlation juga menunjukkan bahwa dimensi-dimensi job embeddedness berkorelasi negatif dengan turnover intentions. Hasil keseluruhan dapat dilihat pada Tabel 2 .

\section{Tabel 2. Ringkasan partial correlation}

\begin{tabular}{lccr}
$\begin{array}{l}\text { Tabel 1. } \\
\text { Deskripsi karakteristik subjek } \\
\text { Karakteristik Subjek }\end{array}$ & Profil & Frekuensi & Persentase \\
\hline Usia & $20-40$ tahun & 152 & $66,4 \%$ \\
& $41-60$ tahun & 77 & $33,6 \%$ \\
Jenis Kelamin & Pria & 90 & $39,31 \%$ \\
& Wanita & 139 & $60,69 \%$ \\
Tingkat Pendidikan & SD & 2 & $0,87 \%$ \\
& SMP & 9 & $3,93 \%$ \\
& SMA/Sederajat & 67 & $29,26 \%$ \\
& D1 & 10 & $4,36 \%$ \\
& D3 & 110 & $48,03 \%$ \\
& S1 & 29 & $12,66 \%$ \\
& S2 & 2 & $0,87 \%$ \\
\hline
\end{tabular}

Kemudian dilakukan analisis regresi untuk melihat kontribusi variabel psychological well-being terhadap turnover intentions dan job embeddedness terhadap turnover intentions. Hasil analisis regresi menunjukkan bahwa psychological wellbeing berpengaruh negatif terhadap turnover Variabel Bebas Turnover

\begin{tabular}{lc} 
& Intentions \\
\hline Psychological Well-being & $-.314^{* *}$ \\
Job Embeddedness & $-.499^{*} k^{*}$ \\
On-the-job embeddedness & $-.446^{* *}$ \\
Off-the-job embeddedness & $-.495^{* *}$ \\
\hline${ }^{*}{ }^{*} \mathrm{p}<0.01$ &
\end{tabular}

intentions dengan nilai $\mathrm{F}=24.883$ dan $\mathrm{p}<0.01$ dan nilai koefisien determinasi $\left(\mathrm{R}^{2}\right)$ sebesar 0.099 atau $9.9 \%$, yang artinya variabel psychological well-being memberikan pengaruh sebesar $9,9 \%$ terhadap turnover intentions. Lebih lanjut dapat dilihat pada Tabel 3.

Selanjutnya hasil analisis regresi menunjukkan bahwa job embeddedness berpengaruh negatif terhadap turnover intentions dengan nilai $\mathrm{F}=75.458$ dan $\mathrm{p}<0.01$ dan nilai koefisien determinasi $\left(\mathrm{R}^{2}\right)$ sebesar 0.249 atau $24.9 \%$, yang artinya variabel job embeddedness memberikan pengaruh sebesar $24,9 \%$ terhadap turnover intentions. Lebih lanjut dapat dilihat pada Tabel 4. 
Tabel 7.

Ringkrasan Koefisien estimasi of -the-job embeddedness tethadap Tunnover Intentions

B Unstandardized Std. Betastandardized F i

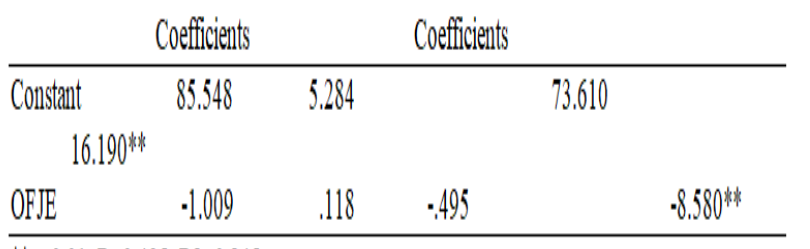



Kemudian dilakukan analisis multiple regression dengan metode enter untuk melihat konstribusi psychological well-being

Tabel 4

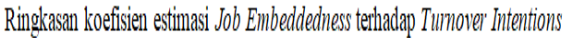

\begin{tabular}{|c|c|c|c|c|c|}
\hline & $\begin{array}{l}\text { B Unstandardized } \\
\text { Coefficients }\end{array}$ & Stod. & $\begin{array}{c}\text { Beta Standardized } \\
\text { Coefficients }\end{array}$ & F & t \\
\hline $\begin{array}{l}\text { Constant } \\
16.282^{\text {*a }}\end{array}$ & 86.205 & 5.295 & & 75.458 & \\
\hline $\mathbb{E}$ & .453 & .052 & - 499 & & $-8.687^{\text {th }}$ \\
\hline
\end{tabular}

dan job embeddedness secara bersama-sama terhadap turnover intentions. Diperoleh nilai $\mathrm{F}=46.052$ dan $\mathrm{p}<0,01$ dan nilai koefisien determinan berganda (R2) sebesar 0,290 atau $29 \%$, yang artinya psychological well-being dan job embeddedness memberikan kontribusi sebesar 29\% terhadap turnover intentions. Dengan demikian, diperoleh persamaan Y $(\mathrm{TI})=98,487-0,408(\mathrm{JE})-$ 0,162 (PWB). Lebih lanjut dapat dilihat pada Tabel 5.

Sementara itu, untuk mengetahui pengaruh dimensi-dimensi job embeddedness tehadap turnover intentions dilakukan analisis regresi. Hasil analisis menunjukkan bahwa kedua dimensi job embeddedness berkontribusi negatif terhadap turnover intentions. Hasil analisis on-the-job embeddedness memiliki nilai $\mathrm{F}=56,286$, $\mathrm{p}<0,01$ dengan nilai koefisien determinan (R2) sebesar 0,199 atau 19,9\%, yang artinya

Tabel 5 .

Ringrasan koefisien estimasi Psychological Well-being dan Job Emberddedness tethadap Turnover Intentions

\begin{tabular}{|c|c|c|c|c|c|}
\hline & $\begin{array}{l}\text { B Unstandardized } \\
\text { Coefficients }\end{array}$ & Std. & $\begin{array}{l}\text { Beta Standadidized } \\
\text { Coefficients }\end{array}$ & $\mathrm{F}$ & $t$ \\
\hline $\begin{array}{l}\text { Constant } \\
15.874^{\text {* }}\end{array}$ & 98.487 & 6.204 & & 46.052 & \\
\hline $\mathrm{JE}$ & -408 & .052 & -450 & & $-7.790^{* 2 k}$ \\
\hline PWB & :162 & .046 & -206 & & $-3,50^{*}$ * \\
\hline
\end{tabular}

on-the-job embeddedness memberikan pengaruh sebesar 19,9\% terhadap turnover intentions. Dengan demikian diperoleh persamaan $\mathrm{Y}(\mathrm{TI})=76,762-0,644(\mathrm{OJE})$. Lebih lanjut dapat dilihat pada Tabel 6.

Selanjutnya hasil analisis off-the-job embeddedness memiliki nilai $\mathrm{F}=73,610$,

$\mathrm{p}<0,01$ dengan nilai koefeisien determinan (R2) sebesar 0,245 atau 24,5\%, yang artinya variabel off-the-job embeddedness

Tabel 6 .

Ringkasan koefisien estimasi on-the-job embeddedness terhadap Turnover Intentions

\begin{tabular}{lccclc} 
& $\begin{array}{c}\text { B Unstandardized } \\
\text { Coefficients }\end{array}$ & $\begin{array}{c}\text { Std. } \\
\text { Coeta Standardized } \\
\text { Coeficients }\end{array}$ & $F$ & $t$ \\
\hline Constant & 76.762 & 4.872 & & 56.286 & \\
$15.757^{\text {** }}$ & & & & & \\
$0 \mathrm{JE}$ & -.644 & .086 & -.446 & & $-7.502^{\text {** }}$ \\
\hline
\end{tabular}

${ }^{*} \mathrm{p}_{\mathrm{p}}<0.01, \mathrm{R}=0.446 ; \mathrm{R}^{2}=0.199$

memberikan pengaruh sebesar 24,5\% terhadap turnover intentions. Dengan demikian diperoleh persamaan $\mathrm{Y}(\mathrm{TI})=$ 
85,548 - 1,009(OFJE). Lebih lanjut dapat dilihat pada Tabel 7.

\section{DISKUSI}

Hasil penelitian ini menunjukkan bahwa psychological well-being berkorelasi negatif dengan turnover intention. Selanjutnya hasil analisis regresi menunjukkan bahwa terdapat pengaruh psychological well-being terhadap turnover intention sebesar 9,9\%, bahwa semakin kuat psychological well-being yang dirasakan karyawan maka akan semakin rendah turnover intention. Hasil pengujian penelitian ini sejalan dengan hasil penelitian Vaart, Linde, Beer \& Cockeran (2014) bahwa psychological well-being dapat memprediksikan turnover intention karyawan. Selanjutnya penelitian yang mendukung hasil pengujian penelitian ini adalah Page dan Vella-Brodrick (2009) dalam hasil penelitiannya menunjukkan bahwa terdapat hubungan negatif yang kuat antara psychological well-being dan turnover intentions.

Beberapa alasan yang dapat menjelaskan pengaruh negatif psychological well-being terhadap turnover intention. Pertama, karyawan yang memiliki psychological well-being yang baik akan memiliki komitmen yang baik dengan organisasi tempatnya bekerja, hal ini didukung dengan hasil penelitian Jain, Giga \& Cooper (2008) yang menunjukkan bahwa psychological well-being memiliki hubungan positif dengan komitmen karyawan. Dalam studi Koslowsky, Weisberg, Yaniv, Zaitman-Speiser (2012) mengemukakan bahwa karyawan yang komitmen terhadap organisasinya dan melihat masa depan dengan melihat keadaan yang sedang ada sekarang mungkin tidak akan sensitif dengan kemungkinan-kemungkinan yang ada di luar organisasi sehingga akan lebih besar kemungkinan karyawan tersebut untuk tetap bertahan pada organisasinya. Kedua, karyawan yang memiliki psychological wellbeing yang baik akan menunjukkan performa yang baik dalam pekerjaannya, hal ini didukung dengan hasil penelitian Polatci \& Akdogan (2014) yang menunjukkan bahwa psychological well-being berhubungan positif dan dapat memprediksikan performa karyawan, ketika psychological well-being seseorang meningkat maka performa karyawan juga akan meningkat. Ketiga, karyawan yang memiliki psychological well-being yang baik akan memiliki kepuasan kerja yang baik, hal ini sejalan dengan hasil penelitian Chitra \& Karunanidhi (2013) yang mengemukakan bahwa terdapat hubungan positif antara psychological well-being dan kepuasan kerja. Hasil penelitian Zhang \& Feng (2011) mengemukakan bahwa kepuasan kerja memiliki hubungan negatif yang signifikan dengan turnover intention, dan menyimpulkan bahwa karyawan yang merasa tidak puas dengan pekerjaannya termasuk reward dan tim kerja akan memunculkan intensi untuk keluar dari pekerjaannya.

Hasil penelitian ini menunjukkan bahwa job embeddedness berkorelasi negatif dengan turnover intention. Selanjutnya hasil analisis regresi menunjukkan bahwa terdapat pengaruh job embeddedness terhadap turnover intention sebesar 24,9\%, bahwa 
semakin kuat job embeddedness yang dirasakan karyaawan maka akan semakin rendah turnover intention. Hasil penelitian ini sejalan dengan hasil penelitian Karatepe (2012) yang menunjukkan bahwa job embeddedness memiliki korelasi negatif dengan turnover intention, sehingga karyawan yang memiliki job embeddedness yang tinggi akan menunjukkan turnover intention yang rendah.

$\begin{array}{cccr}\text { Beberapa } & \text { alasan } & \text { yang dapat } \\ \text { menjelaskan } & \text { pengaruh } & \text { negatif } & \text { job }\end{array}$ embeddedness terhadap turnover intention. Pertama, karyawan yang memiliki job embeddedness yang baik akan memperlihatkan job performance yang baik, hal ini sejalan dengan penelitian Fatima, Shafique \& Qadeer (2015) mengemukakan bahwa job embeddedness, semakin tinggi job embeddedness karyawan akan menunjukkan job performance yang baik dari karyawan. Kedua, job embeddedness dapat memberikan dampak negatif terhadap turnover intentions dikarenakan melalui dimensi job embeddedness yang mencakup faktor organisasi dan komunitas dapat mencerminkan hal-hal yang dapat menahan seorang individu untuk tetap bertahan pada pekerjaannya (Mitchell, Holtom \& Lee, 2001). Yang, $\mathrm{Ma} \& \mathrm{Hu}$ (2011) mengemukakan bahwa job embeddedness mampu untuk mempertahankan seorang individu untuk bertahan pada pekerjaannya dikarenakan kedua faktor pada dimensinya memberikan kontribusi yang penting terhadap keputusan karyawan untuk bertahan pada pekerjaannya.

Hasil utama penelitian ini adalah adanya pengaruh psychological well-being dan job embeddedness terhadap turnover intention, dimana psychological well-being dan job embeddedness memberikan kontribusi sebesar 29,0\% terhadap turnover intentions. Dapat dilihat bahwa pengaruh psychological well-being dan job embeddedness secara bersama-sama terhadap turnover intention lebih besar daripada pengaruh secara tunggal. Hal ini disebabkan adanya dimensi dari variabel psychological well-being dan job embeddedness yang hampir berdekatan yaitu dimensi positive relations with other dari psychological well-being dan dimensi links-organization dan links-community dari job embeddedness. Dapat dilihat bahwa keduanya merupakan hubungan seorang individu dengan orang disekitarnya baik di dalam organisasi dan di luar organisasi. Price (2001) mengemukakan salah satu faktor turnover adalah social support, dimana social support memiliki dampak negatif terhadap turnover.

Hasil utama penelitian ini sejalan dengan hasil penelitian Bretones \& Gonzalez (2011) yang mengemukakan bahwa terdapat hubungan negatif antara psychological wellbeing dengan intensi karyawan untuk meninggalkan organisasi tempatnya bekerja. Bowman (2009) dalam hasil penelitiannya mengemukakan bahwa pada subjek penelitiannya yang berupa petugas polisi menunjukkan bahwa semakin rendah job embeddedness seorang karyawan maka akan semakin tinggi intensi untuk berhenti dari pekerjaannya. Caldarola (2010) dalam hasil penelitiannya mengemukakan bahwa job embeddedness memiliki pengaruh negatif terhadap turnover intentions. Hasil penelitian Khattak, Hussain, Mehmood, Mumtaz, Rehman dan Rehman (2012) 
menunjukkan bahwa job embeddedness dapat mengurangi terjadinya turnover.

Hasil tambahan penelitian ini adalah adanya pengaruh negatif on-the job embeddedness terhadap turnover intention sebesar 19,9\%. Hal ini sejalan dengan hasil penelitian Wheeler, Harris \& Harvey (2010) yang menunjukkan bahwa on-the job embeddedness berpengaruh negatif terhadap turnover intention. Hasil ini juga sejalan dengan hasil penelitian Shafique, Qadeer, Ahmad \& Rehman (2011) yang menunjukkan bahwa on-the-job Embeddedness berpengaruh negatif dan signifikan terhadap turnover intention.

Hasil tambahan penelitian selanjutnya adalah adanya pengaruh negatif off-the job embeddedness terhadap turnover intention sebesar 24,5\%. Hal ini sejalan dengan yang dikemukakan oleh Mitchell, Holtom \& Lee (2001) bahwa seorang individu yang terikat dengan komunitasnya akan mempertahankan pekerjaannya dikarenakan ketika seorang individu kehilangan pekerjaannya maka akan berakibat besar pada kehidupannya dalam komunitas. Hal ini didukung oleh hasil penelitian Rivera, Hom, Martinez, Radillo \& Baron (2013) yang menujukkan bahwa terdapat hubungan yang kuat antara off-the job embeddedness dengan turnover intention.

\section{Kesimpulan}

Hasil penelitian ini menunjukkan bahwa psychological well-being dan job embeddedness memberikan pengaruh negatif terhadap turnover intentions. Turnover merupakan hal yang tidak diinginkan oleh sebuah perusahaan. Tingginya tingkat turnover akan menyebabkan ketidakstabilan pada sebuah organisasi yang menyebabkan bertambahnya biaya-biaya yang tidak seharusnya dikeluarkan, turnover juga akan mempengaruhi produktivitas organisasi dan dapat mempengaruhi lingkungan kerja. turnover intentions merupakan prediktor dari perilaku turnover.

Pada penelitian ini menunjukkan bahwa rata-rata subjek menunjukkan turnover intentions dalam kategori sedang, hal ini sebaiknya mendapatkan perhatian dari perusahaan agar turnover intentions tidak meningkat sehingga menyebabkan tindakan turnover pada karyawan. Perusahaan sebaiknya memperhatikan keterlibatan karyawan, lingkungan kerja dan kebutuhan karyawan agar turnover intentions dapat diminimalisir.

Selanjutnya penelitian ini menunjukkan bahwa rata-rata subjek menunjukkan psychological well-being dalam kategori sedang. Hal ini juga sebaiknya mendapatkan perhatian dari perusahaan agar psychological well-being karyawan dapat ditingkatkan yaitu dengan cara memberikan pembinaan kepada karyawan sehingga mampu untuk memberikan kinerja yang lebih baik.

Hasil penelitian ini juga menunjukkan bahwa rata-rata subjek menunjukkan job embeddedness yang tinggi. Hal ini merupakan hal yang baik untuk karyawan dan perusahaan karena turnover intentions dapat diminimalisir. Perusahaan sebaiknya mempertahankan tingkat job embeddedness yang tinggi tersebut dengan tetap memberikan perhatian terhadap hal-hal yang berhubungan dengan karyawan dari sisi organisasi dan komunitas.

\section{REFERENSI}


Ajzen, I. (1991). The theory of planned behavior. Organizational Behavior and Human Decision Processes, 50, 179211.

Allen, D. G. (2006). Do organizational tactics influence newcomer embeddedness and turnover? Journal of Management, 32(2), 237-256.

Amin, Z., \& Akbar, K. P. (2013) Analysis of Psychological well-being and turnover intentions of hotel employees: An empirical study. International Journal of Innovation and Applied Studies, 3, 662-671.

Andresen, M. (2014). What determines expatriates'performance while abroad? the role of job embeddedness. Journal of Global Mobility, 3, 62-82.

Azwar, S. (2010). Penyusunan skala psikologi. Yogyakarta: Pustaka Pelajar.

Azwar. S. (2012). Penyusunan skala psikologi, Edisi 2. Yogyakarta: Pustaka Pelajar.

Bakker, A.B., Schaufeli, W.B., Leiter, M.P., \& Taris, T.W. (2008). Work engagement: An emerging concept in occupational health. Work and Stress, 22, 187-200.

Beach, R., Brereton, D and Cliff. D. (2003). "Workforce turnover in fly-in/fly-out (FIFO) mining operations in Australia: An exploratory study". Summary Report. Brisbane: Centre for Social Responsibility in Mining.

Besich, J. (2005). Job embeddedness versus traditional models of voluntary turnover: a test of voluntary turnover prediction. A Dissertation. University of North Texas.

Bothma, C.F.C., \& Roodt, G. (2013). The validation of the turnover intention scale. SA Journal of Human Resource Management, 11(1), 507-519.

Bowman, M. D. (2009). A test of direct and partially mediated relationships between leader member exchange, job embeddedness, turnover intentions, and job search behaviors in a southern police department. A Dissertation. Old Dominion University.

Brian, P. (2014). Person-organization fit, job embeddedness and turnover predictability. Proceedings of the 2nd International OFEL Conference on Governance, Management and Entrepreneurship, 538-553.

Bretones, F. D., \& Gonzalez, M. J. (2011). Subjective and occupational wellbeing in a sample of Mexican workers. Soc Indic Res, 100, 273-285.

Caldarola, N. T. (2010). The Effect of Organizational and occupational commitment on job embeddedness and the individual's intention to stay. A Dissertation. TUI University.

Cascio, W. F. (1998). Applied psychology in human resource management (5th.ed). United States of America: PrenticeHall Inc.

Chitra, T., \& Karunanidhi, S. (2013). Influence of occupational stress, resilience, and job satisfaction on psychological well-being of policewomen. Indian Journal of Health and Wellbeing, 4, 724-730. 
Chiu, R. K., \& Francesco, A. M. (2002). Dispositional traits and turnover intentions: Examining the mediating role of job satisfaction and affective commitment. International Journal of Manpower, 24, 284-298.

Dess GG., \& Shaw JD (2001). Voluntary turnover, social capital, and organizational performance. Academy of Management Review., 26: 466-456.

Dike, D. (2011). Quantitative correlational study of organizational culture perception, employment length, and employee turnover in fast-food restaurants. Unpublished doctoral dissertation. University of Phoenix, United States.

Faslah, R. (2010). Hubungan antara keterlibatan kerja dengan turnover intention pada karyawan PT. Garda Trimitra Utama, Jakarta. EconoSains, $8,146-151$.

Fatima, M., Shafique, M., \& Ahmad, R. (2015). HR practices and employee performance relationship in higher education: Mediating role of job embeddedness, perceived organizational support and trust. Pak.j.stat.oper.res, 11, 421-439.

Fishbein, M., \& Ajzen, I. (1975). Belief, attitude, intention, and behavior an introduction to theory and research. Reading; MA: Addison-Wesley.

Fletcher, R. E. (2005). Job embeddedness: A construct of organizational and community attachment utilized to assess voluntary turnover. Wright-
Patterson Air Force Base, OH: Air Force Institute of Technology.

Gilmer, V. H. (1966). Industrial psychology. USA: McGraw Hill Book Company Inc.

Griffeth, R. W., Hom, P. W., \& Geartner, S. (2000). A Meta-analysis of antecedents and correlates of employee turnover: Update, moderator tests, and research implications for the next millennium. Journal of Management, 26(3), 463489.

Halbesleben, J.R.B., \& Wheeler, A.R. (2008). The relative roles of engagement andembeddedness in predicting job performance and intentions to leave. Work \& Stress, 22(3), 242-256.

Harris, G.E and Cameron, J.E. (2005). "Multiple dimensions of organizational identification and commitment as predictors of turnover intentions and psychological well-being". Canadian Journal of Behavioural Science, vol.37, no.3, pp.159-169.

Harter. J. K., Schmidt, F. L., \& Keyes, L. M. (2002). Well being in the workplace and its relationship to business outcomes: A review of the gallup studies (Chapter 9, 205-224). American Psychological Association.

Harter. J. K., Schmidt, F. L., Hayes, T. L. (2002). Business-unit level relationship between employee satisfaction, employee engagement, and business outcomes: A MetaAnalysis. Journal of Applied Psychology, 87, 268-279. 
Hay Group. (2013). Preparing for take off. Hay Group All rights reserved.

Holtom, B. C., \& Inderrieden, E. J. (2006). Integrating the unfolding model and job embeddedness model to better understand voluntary turnover. Journal of Managerial Issues, 18, 435-452.

Huppert, F. A. (2009). Psychological wellbeing: Evidence regarding its causes and consequences. Journal of Health and well-being, I, 137-164.

Jain, A. K., Giga, S. I., \& Cooper, C. L. (2008). Employee wellbeing, control and organizational commitment. Leadership \& Organization Development Journal, 30, 256-273.

Jewel, L. N., \& Siegall, M. (1998). Psikologi industri / organisasi modern. Edisi-2. Jakarta: Arcan (Terjemahan).

Karatepe, O.M., \& Ngeche, R.N. (2012). Does job embeddedness mediate the effect of work engagement? A study of hotel employees in Cameroon. Journal of HospitalityMarketing and Management, 21(94), 440-461.

Khattak, F. U., Hussain, A., Mehmood, Q., Mumtaz, A., Rehman, I.U., \& Rehman, K.U. (2012). Shrinking employees turnover intention by applying tools of job embeddedness (used as a mediator). Information Management and Business Review, 4, 370-378.

Koslowsky, M., Weisberg, J., Yaniv, E. and Zaitman-Speiser, I. (2012), "Ease of movement and sector affiliation as moderators of the organizational and career commitment $\quad-$ turnover intentions link", International Journal of Manpower, Vol. 33 No. 7, pp. 82138.

Lambert, E. G., Hogan, N. L., \& Barton, S. M. (2001). The impact of job satisfaction on turnover intention: A test of a structural measurement model using a national sample of workers. The Social Science Journal, 38, 233250.

Lambert, E. G., Cluse-Tolar, T., Pasupuleti, S., Prior, M., \& Allen, R. I. (2012). A test of a turnover intent model. Administration in Social Work, 36, 6784.

Loi, R., Hang-yue, N., \& Foley, S. (2006). Linking employees' justice perceptions to organizational commitment and intention to leave: The mediating role of perceived organizational support. Journal of Occupational and Organizational Psychology, 79, 101120.

Macdonald, C. A. (2010). Working group on health and well-being in the workplace; White paper-psychological well being at work. The British Psychological Society, 1-12.

Michael Page. (2015). 2015 Employee Intentions Report Indonesia. Michael Page All rights reserved.

Mitchell, T.R., Holtom, B.C., \& Lee, T.W. (2001). Why people stay: Using job embeddedness to predict voluntary turnover. Academy of Management Jourrnal,44, 1102-1121.

Mobley, W. H., Griffith, R.W., Hand, H.H. \& Meglino, B.M. (1979). Review and 
conceptual analysis of the employee turnover process. Psychological Bulletin, 36, 493-521.

Mobley, W.H. (1982). Some Unanswered Questions in Turnover and Withdrawal Research. The Academy of Management Review, 111-116.

Mobley, W.H. (2011). Pergantian karyawan: Sebab, akibat, dan pengendaliannya. Terjemahan. Jakarta: IPPM \& PT Pustaka Binaman Pressindo.

Mufunda, J. (2006). Performance appraisal system impact on university academic staff job satisfaction and productivity. Performance Improvement Quarterly, 19, 117-126.

Munawaroh. (2012). Panduan Memahami Metodologi Penelitian. Cetakan Pertama. PT.Intimedia.

Navei, W. (2015). The effect of job embeddedness on organizational cynicism and employee performance: A study on sadat city university. International Journal of Business Administration, 6, 8-25.

Page, K. M., \& Vella-Brodrick, D. A. (2009). The 'what', 'why' and 'how' of employee well-being: a new model. Soc Indic Res, 90, 441-458.

Papalia, D. E., Olds, S. W., \& Feldman, R. D. (2008). Human development, 9th ed. Boston: McGraw Hill Company, Inc.

Piyachat, B., \& Chanongkorn, K. (2015). Guidelinesfor improving productivity, inventory, turnover rate, and level of defects in thailand plastic industry.
Indian Journal of management Science, V, 65-71.

Polatci, S., \& Akdogan, A. (2014). Psychological capital and performance: The mediating role of work family spillover and psychological well being. Business and Economics Research Journal, 5, 1-15.

Price, J. (2001). Reflections on the determinants of voluntary turnover. International Journal of Manpower 22, 600-624.

Radzi, S. M., Ramley, S. Z. A., Salehuddin, M., \& Oathman, Z., \& Jalis, M. H. (2009). An Empirical assessment of hotel departmental manager turnover intentions: The Impact of organizational justice. International Journal of Business Management, 4, 8, 173-183.

Ramesh A,, \& Gelfand, MJ. (2010). Will they stay or will they go? The role of job embeddedness in predicting turnover in individualistic and collectivistic cultures. Journal of Applied Psychology, 95(5): 1-17.

Rivera, B. R. G., Hom, P. W., Martinez, I. A. M., Radillo, S. E. M., \& Baron, C. R. (2013). Turnover and job embeddedness in tijuana mexico. Global Journal of Business Research, 7, 113-122.

Ryff, C. D. (1989). Happiness is everything, or is it? Explorations on the meaning of psychological well-being. Journal of Personality and Social Psychology, 57, 1069-1081. 
Ryff, C. D., \& Keyes, C. L. M. (1995). The structure of psychological well-being revisited. Journal of Personality and Social Psychology, 69,719-727.

Santoso, S. (2002). Statistik multivariate. Jakarta: PT. Elex Media Komputindo.

Shafique, M., Qadeer, F., Ahmad, M., \& Rehman, R. (2011). Impact of job embeddedness on leave intention: an understanding from higher education (HE) system. African Journal of Business Management, 5, 1179411801

Sharma, A., \& Nambudiri, R. (2013). Jobleisure conflict, turnover intention and the role of job satisfaction as a mediator: an empirical study of indian IT professionals. South Asian Journal of Management, 22, 7-27.

Singh, A. P., \& Amish. (2015). Role of trustworthy behavior in turnover intention among front level managerial personnel. Journal of the Indian Academy of Applied Psychology, 41, 94-102.

Sousa-Poza, A., \& Henneberger, F. (2002). Analyzing job mobility with job turnover intentions: An international comparative study. Research Institute for Labour Economics and Labour Law, 82, 1-28.

Staw, B.M. (1980). The consequences of turnover. J. Occupat. Behav., 1: 253273.

Stetz, M. C., Castro, C. A., \& Bliese, P. D. (2007). The impact of deactivation uncertainty, workload, and organizational constraints on reservists' psychological well-being and turnover intentions. Military Medicine, 172, 576-580.

Sunyoto, D. (2013). Metode dan Instrumen Penelitian Ekonomi dan Bisnis. Jakarta: Center for Academic Publishing Service.

Suryabrata, S. (2011). Metodologi Penelitian. Jakarta : Raja Grafindo Persada.

Suwandi \& Indriantoro (1999). Model turnover pasewark \& Strawser: Studi empiris pada lingkungan akuntansi publik. Jurnal Riset Akuntansi Indonesia. 2(2), 173-195.

Takawira, N., Coetzee, M., \& Schreuder, D. (2014). Job embeddedness, work engagement and turnover intentions of staff in a higher education institution: An exploratory study. Journal of human resource management, 12, 110.

Tanova, C., \& Holtom, B. (2008), “Using job embeddedness factors to explain voluntary turnover in 4 European countries", International Journal of Human Resource Management, Vol. 19 No. 9. 1553-68.

Tjutju, Y. (2008). Manajemen sumber daya manusia. Bandung: Alfabeta.

Towers Watson. (2013). Benefits \& Compensation International Total Remuneration and Pension Investment. Pension Publications Limited, London, England.

Vaart, L. V. D., Linde, B., Beer, L., \& Cockeran, M. (2014). Employee wellbeing, intention to leave and perceived 
employability : a psychological contract approach. SAJEMS NS, 18, 32-44.

Vandenberg, R.J and Nelson, J.B. (199). "Disaggregating the motives underlying turnover intentions: When do intentions predict turnover behavior?" Human Relations,no.52, pp.1313-1336.

Wheeler, A. R., Harris, K. J., \& Harvey, P. (2010), "Moderating and mediating the HRM effectiveness-intent to turnover relationship: the roles of supervisors and job embeddedness", Journal of Managerial Issues, 22, 182-196.

Wibisono, D. (2003). Riset bisnis, panduan bagi praktisi dan akademisi. Jakarta: Gramedia Pustaka Utama.

Wijayanto, B. R., \& Kismono, G. (2004). The effect of job embeddedness on organizational citizenship behavior: the mediating role of sense of responsibility. Gadjah Mada International Journal of Business, 6, 335-354.

Wilson, A. A. (2006). The lone wolf phenomenon: the impact of commitment and performance on turnover intention in sales. A Dissertasion. Alliant International University.

Wright, T. A., Cropanzano, R., \& Bonett. D. G. (2007) The moderating role of employee positive well-being on the relation between job satisfaction and job performance. Journal of Occupational Health Psychology, 12, 93-104.
Wright. (2009). The role of employee psychological well-being in cardiovascular health: When the twain shall meet. Journal of Organizational Behaviour, 30,193-208.

www.compdatasurveys.com/benchmarkpro/

Yang, C., Ma, Q., \& Hu, L. (2011). Job embeddedness: a new perspective to predict voluntary turnover. Nankai Business Review International, 2, 418446.

Zahoor, Z. (2015). A comparative study of psychological well-being and job satisfaction among teachers. Indian Journal of Health and Wellbeing, 6, 181-184.

Zhang, Y., \& Feng, X. (2011). The relationship between job satisfaction, burnout, and turnover intention among physicians from urban state-owned medical institutions in Hubei, China: a cross-sectional study. BMC Health Service Research, 11, 1-13. 
